\title{
An integrated modeling framework for coevolution and feedback loops of nexus across economy, ecology and food systems based on the
}

\section{sustainable development of water resources}

By Yaogeng Tan*, Zengchuan Dong, Sandra M. Guzman, Xinkui Wang, Wei Yan

\section{Appendix B: Supplementary materials (Data availability)}

\section{S1 Constraints of the model}

(1) Constraints of continuity equation between subareas and reservoir

For each water supply subsystem, a reservoir supplies water to each subarea (the lower level in Fig.3). Therefore, reservoir is interconnected with each subarea. Among subareas, they also have the continuity relationship of the upper and lower reach of the river. It can be expressed as follows:

$$
I_{k t}=\sum_{j=1}^{J} W S_{j k t}^{r s v}+\sum_{k \in \Omega} W R_{k-1, t}+W I F_{k t}
$$

where $\mathrm{I}_{\mathrm{kt}}$ is the total water income of subarea $\mathrm{k}$ in time $\mathrm{t}, \mathrm{WS}^{\mathrm{rsv}}$ is water supply only from reservoir, WR is water recession to the downstream subarea(s). Subscript $\mathrm{j}$ represents different water users. WIF is the intermediate flow between (k-1)th and kth subarea. $\Omega$ is the summary of the direct upper reaches of kth subarea.

(2) Constraints of the water balance of reservoir

$$
V_{t}+Q N_{t}-\sum_{j=1}^{J} \sum_{k=2}^{K} W S_{j k t}^{r s v}-W_{t}^{l o s s}-Q_{t}=V_{t+1}
$$

where $\mathrm{V}_{\mathrm{t}}$ is water volume in the reservoir at time $\mathrm{t}, \mathrm{W}^{\text {loss }}$ is the water loss of evaporation and leakage of the reservoir.

(3) Constraints of the water balance of subarea

$$
W_{k t}+I_{k t}-\sum_{j=1}^{J} W S_{j k t}-W R_{k t}=W_{k, t+1}
$$

where $\mathrm{W}_{\mathrm{kt}}$ is total quantity of water resources in subarea $\mathrm{k}$ in time $\mathrm{t}$.

(4) Water supply constraint

Water allocated to each subarea should not exceed the capacity of each water project.

$$
W S_{i, t} \leq W S_{i, \max }
$$

(5) Water demand constraint

For decreasing the waste of water resources, water allocated to each subarea should not exceed the water demand. If there is abundant water, the extra water that exceeds the water demand should be stored in the water project.

$$
0 \leq W S_{j k t} \leq W D_{j k t}
$$


(6) Reservoir volume constraint

The lower and upper limit of the reservoir should be considered to keep the reservoir safety.

$$
V_{\min } \leq V_{t} \leq V_{\max }
$$

(7) Non-negative constraint

All the variables in this model should be non-negativity.

\section{S2. Whole procedure of decomposition-coordination and dynamic programming}

The total procedure of DC is classified into four steps. First, the whole system is decomposed into three-level hieratical structure (upper level, middle level and lower level) and subsystems (see Fig.2 and Fig.3). The upper level represents the whole system, middle level a reservoir subsystem, and lower level represents and individual reservoir \& subarea. The DC process is classified into 2 layers: internal subsystem of water supply and the relation between water supply subsystems. For each internal reservoir subsystem, the Lagrange function is presented to describe the model objective:

$$
\begin{aligned}
& L=\alpha\left(F_{\text {ecnmy }}+F_{\text {veg }}+F_{\text {food }}\right)+\theta F_{r i v}+\sum_{t=1}^{T} \sum_{k=1}^{K_{1}} \lambda_{k t}\left(\sum_{j=1}^{J} W S_{j k t}^{r s v}+\sum_{k \in \Omega} W R_{k-1, t}+W I F_{k t}-I_{k t}\right) \\
& +\sum_{t=1}^{T} \mu_{1, k t}\left(V_{t}+Q N_{t}-\sum_{j=1}^{J} \sum_{k=1}^{K_{1}} W S_{i k t}^{r s v}-W_{t}^{l o s s}-Q_{t}-V_{t+1}\right) \\
& +\sum_{t=1}^{T} \sum_{k=1}^{K_{1}} \mu_{2, k t}\left(W_{k t}+I_{k t}-\sum_{j=1}^{J} W S_{j k t}-W R_{k t}-W_{k, t+1}\right)
\end{aligned}
$$

where $\lambda, \mu_{1}$ and $\mu_{2}$ are slack variables, $K_{1}$ is the number of subareas in a reservoir water supply subsystem. The last two items of Eq.(S1) are 0 when water balance equation is satisfied (Li et al.,2015). Thus, the Lagrange function can be rewritten as the additive separable form (Jia et al., 2015):

$$
L=\sum_{t=1}^{T}\left\{\left[\theta F_{r i v}+\sum_{i=1}^{I} \sum_{k=1}^{K_{1}} \lambda_{k t} W S_{i k t}^{r s v}\right]+\sum_{k=1}^{K_{1}}\left[\alpha\left(F_{\text {ecnmy }}+F_{v e g}+F_{f o o d}\right)+\lambda_{k t}\left(\sum_{k \in \Omega} W R_{k-1, t}+W I F_{k t}-I_{k t}\right)\right]\right\}
$$

Eq.(S2) is the Lagrange function that summarizes the objective function of each subarea and reservoir. For the layer that describes the relation between water supply subsystems, the optimal solution for whole system is the summary of Eq.(S2) of each water supply subsystems.

Following the objective function between subareas is the coordination between those subareas and reservoir in each reservoir supply subsystem. Coordinate variables are treated as the independent variables. According to the dual theory, the necessary condition of optimal solution of Lagrange function is that the derivative to the model variables should be zero (Jia et al., 2015), and gradient method was used to solve the optimal coordinate variables:

$$
\lambda_{k t}^{m+1}=\lambda_{k t}^{m}+\sigma_{m} \cdot \frac{\partial L}{\partial \lambda_{k t}^{m}}
$$

The third step is the optimization of subareas and reservoir. Considering water management can be divided into several time steps, dynamic programming (DP) is used in optimization process. DP mainly includes four elements that listed below: 
(1) Stage variable: each time step is selected as the stage variable.

(2) State variable: the initial water amount in each subsystem is selected as stage variable. In this case, it is reflected by the initial storage of reservoir and total amount of water in each administrative region.

(3) Decision variable: total water supply for each subarea and actual streamflow of reservoir is selected as decision variable.

(4) Recurrence formulation:

$$
f\left(S_{t}\right)=\min \left\{v\left(S_{t}, D_{t}\right)+f\left(S_{t+1}\right)\right\}
$$

where $S_{t}$ and $D_{t}$ is the state and decision variable at th stage, $f\left(S_{t}\right)$ is the optimal benefit of the whole system at the state $\mathrm{S}_{\mathrm{t}} ; \mathrm{v}\left(\mathrm{S}_{\mathrm{t}}, \mathrm{D}_{\mathrm{t}}\right)$ is the benefit with the decision $\mathrm{D}_{\mathrm{t}}$ at the state $\mathrm{S}_{\mathrm{t}}$.

The last step is to combine the first three steps because the process of decomposition, coordination and subsystem optimization is interrelated. The procedure of the whole DC method is as follows:

(1) Generate initial solution of each subarea and reservoir with a given initial value. The solution includes the actual reservoir streamflow and total water supply of each subarea.

(2) Calculate the coordinative variables based on the initial solution based on Eq.(9), and optimizing the solution of each subsystem by using DP based on the calculated coordination variables.

(3) Compare the optimized solution in (2) with the initial solution. If the error is within the given precision $(\varepsilon=0.0001)$, it is the final solution. Otherwise, recalculate the new coordinative variables and repeat the procedure until the error is within the specific range.

(4) Optimize the next reservoir supply subsystem and the summary of each subsystem is the global optimal solution. 


\section{S3. Detailed flowchart of system dynamics and equations of EEF nexus}

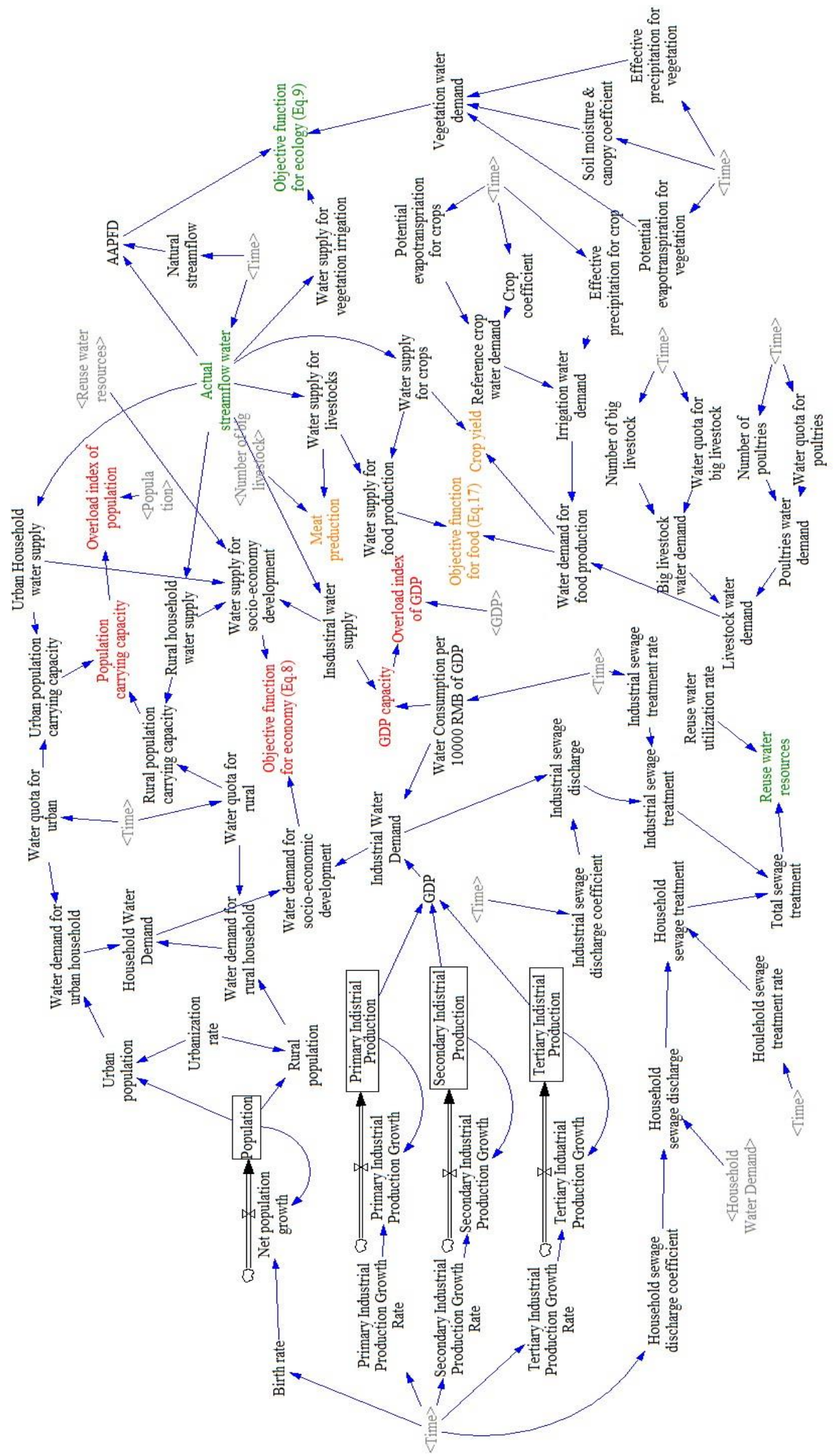

Fig.S1 Dynamic analysis framework of EEF nexus based on SD model

To distinguish, the variable that can reveal the coevolution of EEF nexus is shown in different colors. Red for economic, orange for food and green for ecology. The main equations of SD model 
are shown in Table S1.

Table S1. Main equations of SD model

\begin{tabular}{|c|c|c|}
\hline Variables & Unit & Equations \\
\hline Birth rate & $\%$ & See Table 4 \\
\hline Industrial growth rate & $\%$ & See Table 4 \\
\hline GDP & $10^{4}$ yuan & $\begin{array}{c}\text { Primary industrial production }+ \text { Secondary industrial } \\
\text { production }+ \text { Tertiary industrial production }\end{array}$ \\
\hline $\begin{array}{l}\text { Industrial water } \\
\text { demand }\end{array}$ & $10^{4} \mathrm{~m}^{3}$ & GDP $\times$ Water consumption per 10000 RMB of GDP \\
\hline Urbanization rate & $\%$ & $\begin{array}{c}=\text { WITHLOOKUP }\{\text { Time },[(2016,0.3317)- \\
(2040,0.4958)],(2016,0.3499),(2017,0.3550), \\
(2018,0.3601),(2019,0.3652),(2020,0.3704), \\
(2021,0.3780),(2022,0.3856),(2023,0.3933), \\
(2024,0.4010),(2025,0.4088),(2026,0.4166), \\
(2027,0.4245),(2028,0.4323),(2029,0.4403), \\
(2030,0.4482),(2031,0.4530),(2032,0.4578), \\
(2033,0.4625),(2034,0.4673),(2035,0.4720), \\
(2036,0.4768),(2037,0.4815),(2038,0.4863), \\
(2039,0.4910),(2040,0.4958)\}\end{array}$ \\
\hline Water quota for urban & L/person/d & 200 \\
\hline Water quota for rural & $\mathrm{L} /$ person/d & 120 \\
\hline Urban population & People & Population $\times$ Urbanization rate \\
\hline Rural population & People & Population $\times(1$-Urbanization rate $)$ \\
\hline $\begin{array}{l}\text { Water demand for } \\
\text { urban household }\end{array}$ & $10^{4} \mathrm{~m}^{3}$ & See Eq.(1a) \\
\hline $\begin{array}{l}\text { Water demand for } \\
\text { urban household }\end{array}$ & $10^{4} \mathrm{~m}^{3}$ & See Eq.(1a) \\
\hline $\begin{array}{l}\text { Household water } \\
\text { demand }\end{array}$ & $10^{4} \mathrm{~m}^{3}$ & $\begin{array}{l}\text { Water demand for urban household + Water demand for } \\
\text { urban household }\end{array}$ \\
\hline $\begin{array}{l}\text { Water demand for } \\
\text { socio-economic } \\
\text { development }\end{array}$ & $10^{4} \mathrm{~m}^{3}$ & Household water demand + Industrial water demand \\
\hline $\begin{array}{l}\text { Urban household water } \\
\text { supply }\end{array}$ & $10^{4} \mathrm{~m}^{3}$ & Solved by optimal model \\
\hline $\begin{array}{l}\text { Rural household water } \\
\text { supply }\end{array}$ & $10^{4} \mathrm{~m}^{3}$ & Solved by optimal model \\
\hline $\begin{array}{l}\text { Water supply for socio- } \\
\text { economy development }\end{array}$ & $10^{4} \mathrm{~m}^{3}$ & $\begin{array}{l}\text { Urban household water supply + Rural household water } \\
\text { supply + Reuse water resources }\end{array}$ \\
\hline $\begin{array}{l}\text { Urban population } \\
\text { carrying capacity }\end{array}$ & people & $\begin{array}{l}\text { Urban household water supply } \times 1000 / \text { (Water quota for } \\
\text { urban } \times 365)\end{array}$ \\
\hline $\begin{array}{l}\text { Rural population } \\
\text { carrying capacity }\end{array}$ & people & $\begin{array}{l}\text { Rural household water supply } \times 1000 / \text { (Water quota for } \\
\text { rural } \times 365)\end{array}$ \\
\hline $\begin{array}{l}\text { Population carrying } \\
\text { capacity }\end{array}$ & people & $\begin{array}{c}\text { Urban population carrying capacity }+ \text { Rural population } \\
\text { carrying capacity }\end{array}$ \\
\hline
\end{tabular}




\begin{tabular}{|c|c|c|}
\hline $\begin{array}{l}\text { Overload index of } \\
\text { population }\end{array}$ & - & Population/Population carrying capacity \\
\hline Industrial water supply & $10^{4} \mathrm{~m}^{3}$ & Solved by optimal model \\
\hline GDP capacity & $10^{4}$ yuan & $\begin{array}{l}\text { Industrial water supply/Water consumption per } \\
\text { 10000RMB of GDP }\end{array}$ \\
\hline $\begin{array}{l}\text { Overload index of } \\
\text { GDP }\end{array}$ & - & GDP/GDP capacity \\
\hline $\begin{array}{c}\text { Household sewage } \\
\text { discharge coefficient }\end{array}$ & - & 0.75 \\
\hline $\begin{array}{l}\text { Household sewage } \\
\text { discharge }\end{array}$ & $10^{4} \mathrm{~m}^{3}$ & $\begin{array}{l}\text { Household water demand } \times \text { Household sewage discharge } \\
\text { coefficient }\end{array}$ \\
\hline $\begin{array}{l}\text { Household sewage } \\
\text { treatment rate }\end{array}$ & - & 0.75 \\
\hline $\begin{array}{l}\text { Household sewage } \\
\text { treatment }\end{array}$ & $10^{4} \mathrm{~m}^{3}$ & $\begin{array}{c}\text { Household sewage discharge } \times \text { Household sewage } \\
\text { treatment rate }\end{array}$ \\
\hline $\begin{array}{c}\text { Industrial sewage } \\
\text { discharge coefficient }\end{array}$ & - & 0.7 \\
\hline $\begin{array}{l}\text { Industrial sewage } \\
\text { discharge }\end{array}$ & $10^{4} \mathrm{~m}^{3}$ & $\begin{array}{l}\text { Industrial water demand } \times \text { Industrial sewage discharge } \\
\text { coefficient }\end{array}$ \\
\hline $\begin{array}{l}\text { Industrial sewage } \\
\text { treatment rate }\end{array}$ & - & 0.7 \\
\hline $\begin{array}{c}\text { Industrial sewage } \\
\text { treatment }\end{array}$ & $10^{4} \mathrm{~m}^{3}$ & $\begin{array}{c}\text { Industrial sewage discharge } \times \text { Industrial sewage } \\
\text { treatment rate }\end{array}$ \\
\hline Total sewage treatment & $10^{4} \mathrm{~m}^{3}$ & $\begin{array}{c}\text { Household sewage treatment }+ \text { Industrial sewage } \\
\text { treatment }\end{array}$ \\
\hline $\begin{array}{l}\text { Reuse water utilization } \\
\text { rate }\end{array}$ & - & 0.2 \\
\hline Reuse water resources & $10^{4} \mathrm{~m}^{3}$ & Total sewage treatment $\times$ Reuse water utilization rate \\
\hline Number of livestock & $10^{4}$ number & $\begin{aligned} &= \text { WITHLOOKUP }\{\text { Time },[(2016,256)-(2040,306)], \\
&(2016,256),(2017,258),(2018,260),(2019,262), \\
&(2020,263),(2021,265),(2022,267),(2023,269), \\
&(2024,271),(2025,274),(2026,276),(2027,278), \\
&(2028,280),(2029,282),(2030,284),(2031,286), \\
&(2032,288),(2033,290),(2034,293),(2035,295), \\
&(2036,297),(2037,299),(2038,301),(2039,304), \\
&(2040,306)\}\end{aligned}$ \\
\hline $\begin{array}{l}\text { Water quota for big } \\
\text { livestock }\end{array}$ & $\mathrm{L} /$ number/d & 100 \\
\hline $\begin{array}{l}\text { Big livestock water } \\
\text { demand }\end{array}$ & $10^{4} \mathrm{~m}^{3}$ & See Eq.(1a) \\
\hline Number of poultries & $10^{4}$ number & $\begin{array}{l}=\text { WITHLOOKUP }\{\text { Time, }[(2016,6870)-(2040,8220)], \\
(2016,6870),(2017,6922),(2018,6974),(2019,7026), \\
(2020,7078),(2021,7132),(2022,7186),(2023,7239), \\
(2024,7294),(2025,7348),(2026,7404),(2027,7459),\end{array}$ \\
\hline
\end{tabular}




\begin{tabular}{|c|c|c|}
\hline & & $\begin{array}{c}(2028,7515),(2029,7571),(2030,7628),(2031,7685), \\
(2032,7743),(2033,7801),(2034,7859),(2035,7918), \\
(2036,7977),(2037,8037),(2038,8098),(2039,8159), \\
(2040,8220)\}\end{array}$ \\
\hline $\begin{array}{l}\text { Water quota for } \\
\text { poultries }\end{array}$ & $\mathrm{L} /$ number/d & 1.5 \\
\hline $\begin{array}{l}\text { Poultries water } \\
\text { demand }\end{array}$ & $10^{4} \mathrm{~m}^{3}$ & See Eq.(1a) \\
\hline $\begin{array}{l}\text { Livestock water } \\
\text { demand }\end{array}$ & $10^{4} \mathrm{~m}^{3}$ & Big livestock water demand + Poultries water demand \\
\hline $\begin{array}{l}\text { Reference crop } \\
\text { demand }\end{array}$ & $10^{4} \mathrm{~m}^{3}$ & $\begin{array}{l}\text { Potential evapotranspiration for crops } \times \text { Crop coefficient } \\
\qquad \text { (See Eq.(5)) }\end{array}$ \\
\hline $\begin{array}{l}\text { Irrigation water } \\
\text { demand }\end{array}$ & $10^{4} \mathrm{~m}^{3}$ & Reference crop demand- effective precipitation for crop \\
\hline $\begin{array}{l}\text { Water demand for food } \\
\text { production }\end{array}$ & $10^{4} \mathrm{~m}^{3}$ & Livestock water demand + Irrigation water demand \\
\hline Crop yield & $10^{4} \mathrm{t}$ & $\begin{array}{l}\text { f(Water supply for crops, water demand for food } \\
\text { production), see Eq.(6) }\end{array}$ \\
\hline
\end{tabular}

\section{S4. Three-level hieratical structure model in ULRB}

As mentioned in section 2.2.1, the optimal model can be conceptualized as three-level hieratical structure model. In ULRB, there are seven reservoirs and their corresponding water recipient regions is listed in Table S1. Therefore, there are seven reservoir supply systems, i.e., seven subsystems. For each subsystem, it includes a reservoir and subareas and listed in each row in Table S3.

Table S3. Parameters of reservoirs and corresponding water recipient regions

\begin{tabular}{|l|l|l|l|l|l|l|}
\hline $\begin{array}{l}\text { Abbreviation } \\
\text { Shown in } \\
\text { Fig.4) }\end{array}$ & Full name & $\begin{array}{l}\text { Initial year } \\
\text { constructed }\end{array}$ & $\begin{array}{l}\text { Total } \\
\text { storage } \\
\left(10^{4}\right. \\
\left.\mathrm{m}^{3}\right)\end{array}$ & $\begin{array}{l}\text { Dead } \\
\text { storage } \\
\left(10^{4} \mathrm{~m}^{3}\right)\end{array}$ & $\begin{array}{l}\text { Yearly } \\
\text { average } \\
\text { inflow } \\
\left(\mathrm{m}^{3} / \mathrm{s}\right)\end{array}$ & $\begin{array}{l}\text { Subareas/Water } \\
\text { recipient region } \\
(\text { City or county })\end{array}$ \\
\hline FZK & Fuzikou & 2011 & 18000 & 920 & 8.53 & Xing'an \\
\hline CJ & Chuanjiang & 2009 & 9787 & 346 & 15.44 & Xing'an \\
\hline XRJ & Xiaorongjiang & 2010 & 16200 & 670 & 13.34 & Xing'an \\
\hline QST & Qingshitan & 1964 & 41500 & 4600 & 28.09 & $\begin{array}{l}\text { Guilin urban } \\
\text { area, } \\
\text { Lingchuan, } \\
\text { Lingui }\end{array}$ \\
\hline SAJ & Si'anjiang & 2006 & 8323 & 213 & 26.94 & $\begin{array}{l}\text { Lingchuan, } \\
\text { Yangshuo }\end{array}$ \\
\hline JS & Junshan & 1990 & 12000 & 590 & 27.61 & $\begin{array}{l}\text { Pingle, } \\
\text { Gongcheng }\end{array}$ \\
\hline DJ & Dajiang & 1960 & 8140 & 530 & 12.52 & Lipu \\
\hline
\end{tabular}

In this table, we can see that some counties receive water from more than 1 reservoir. For example, Xing'an county receives water from FZK, CJ and XRJ, while Lingchuan county receive 
water from XRJ, QST and SAJ. To overcome this problem, these counties can be further spilt into towns. As there are 3 towns, named Huajiang, Rongjiang and Yanguan that belongs to Xing'an County, FZK, CJ and XRJ was set to supply water for Huajiang, Rongjiang and Yanguan towns, respectively. For the same reason, as Lingchuan county is big and receive water from 2 reservoirs (QST and SAJ), it can be also split into towns and the reservoirs supply water for the nearest towns. The detailed for Lingchuan county is shown in Table S4.

Table S4. Water recipient regions for Lingchuan County

\begin{tabular}{|c|c|}
\hline Reservoirs & Water recipient region (town) \\
\hline Qingshitan & Sanjie, Lantian, Qinshitan, Tanxia, Lingchuan, Dingjiang, Gantang \\
\hline Si'anjiang & Dajing, Lingtian, Haiyang, Dawei, Chaotian \\
\hline
\end{tabular}

Also, according to the three-level hierarchical structure presented in Fig.3 of Section 2.2.1 and the physical condition of ULRB, the three-level hierarchical structure of ULRB is shown in Fig.S2.

\section{S5. Data sources of ULRB}

Table S2. Data sources and its usages

\begin{tabular}{|c|c|c|}
\hline Data & Sources & Usage \\
\hline $\begin{array}{l}\text { Population, GDP as well } \\
\text { as natural growth rate, } \\
\text { livestock numbers }\end{array}$ & $\begin{array}{l}\text { Ching City Statistical Yearbook } \\
\text { (2000-2014) } \\
\text { Socio-economic statistical yearbook } \\
\text { of Guilin city (2000-2014); } \\
\text { Socio-economic statistical yearbook } \\
\text { of Guangxi (2000-2014); } \\
\text { Urban comprehensive planning of } \\
\text { Guilin City } \\
\text { Kandasamy et al., (2014) }\end{array}$ & $\begin{array}{l}\text { Predict future population } \\
\text { including livestock }\end{array}$ \\
\hline $\begin{array}{l}\text { Meteorological data } \\
\text { (Precipitation, } \\
\text { temperature, relative } \\
\text { humidity, sunshine } \\
\text { duration) }\end{array}$ & $\begin{array}{l}\text { Weather stations (shown in Fig.5) } \\
\text { (http://data.cma.cn) (1958-2013) }\end{array}$ & $\begin{array}{l}\text { Main input }\left(\mathrm{ET}_{0}\right) \text { of crop } \\
\text { yield equation and vegetation } \\
\text { water demand }\end{array}$ \\
\hline Water use quota & $\begin{array}{l}\text { Water industry standard of People's } \\
\text { Republic of China }\end{array}$ & $\begin{array}{l}\text { Predict water demands of } \\
\text { water users }\end{array}$ \\
\hline Crop \& vegetation area & $\begin{array}{l}\text { Resource and Environment Data } \\
\text { Cloud Platform, China Academy of } \\
\text { Sciences } \\
\text { (http://www.resdc.cn) (2015) }\end{array}$ & $\begin{array}{l}\text { Crop and vegetation water } \\
\text { demand }\end{array}$ \\
\hline Reservoir inflow & $\begin{array}{l}\text { Hydrological yearbooks }(1958- \\
2013)\end{array}$ & Input of optimal model \\
\hline $\begin{array}{l}\text { Historical water usage of } \\
\text { livestock }\end{array}$ & $\begin{array}{l}\text { Water Resources Bulletin of Guilin } \\
(2000-2014)\end{array}$ & $\begin{array}{l}\text { Building regression equation } \\
\text { of livestock number and its } \\
\text { water usage }\end{array}$ \\
\hline $\begin{array}{l}\text { Sewage treatment rate \& } \\
\text { reuse water recycling rate }\end{array}$ & Water Resources Bulletin of Guilin & Calculating reuse water \\
\hline
\end{tabular}




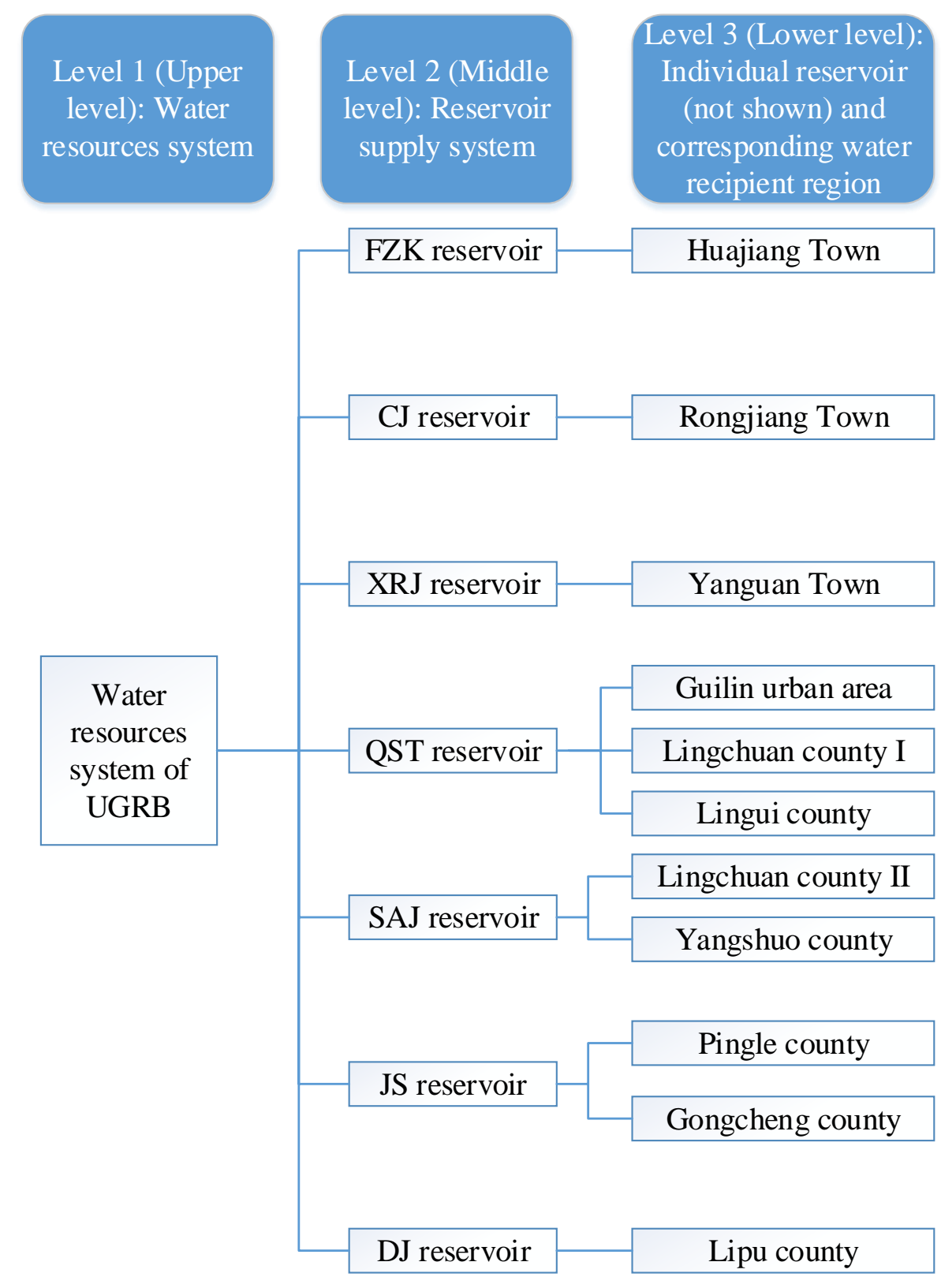

Notes: 1. Huajiang, Rongjiang and Yanguan town belong to Xing an county; 2. Lingchuan county I and II are the water recipient region of QST and SAJ reservoir, the corresponding towns are shown in Table S4.

Fig.S2 Three-level hierarchical structure of ULRB

\section{References}

Jia, B.; Zhong, P.; Wan, X.; Xu, B.; Chen, J.: Decomposition-coordination model of reservoir group and flood storage basin for real-time flood control operation. Hydro. Res. 46, 11-25, 2015.

Li, C.; Zhou, J.; Ouyang, S.; Wang, C.; Liu, Y.: Water Resources Optimal Allocation Based on Largescale Reservoirs in the Upper Reaches of Yangtze River. Water Resour. Manag. 29, 2171-2187, 2015 . 